herligende tragik til mild forklarelse, over Ecce Homo, hvor den skrivende - ifølge Detering i ramme alvor identificerer sig som korsdrager i en gentaget passionshistorie, og til sidst de pseudonyme breve, hvor Antikrist og den korsfæstede er blevet én, hvor Gud atter er på jord og vil denne jord netop som den er.

Det, der står tilbage hos den sene Nietzsche er ikke et dionysisk volds- og magtorgie, men derimod en "Gesammt-Verklärungs-Gefühl aller Dinge (die Seligkeit)" (KSA 6, 207), "eine Sanftmut aus Stärke" (s. 156), hedder det.

\section{Detering tager} kristusidentifikation

Nietzsches alvorligt, meget alvorligt. Velsagtens for alvorligt for nogles smag. Men argumentet er besnærende og dertil vældig stringent og overmåde tekstnært udført; Nietzsche endte i den forklarede mildhed - måske.

Men betyder dette så, at kristendommens selvbestaltede dødsfjende endte som kristen? Ingenlunde, og det postulerer Detering heller ikke. Langt snarere vidner vendingen mod Jesus, hvis altså man tager den besnærende rekonstruktion for gode varer, vel blot om, at også Nietzsche i lighed med så mange andre $i$ den vestlige åndshistorie tilsidst fandt (fremdigtede) sin Jesus, en Jesus der som så mange andres ikke var identisk med den af kirken forkyndte.

Ansporende læsning for den, der kan finde interesse i en litterær kontinuitetsorienteret Nietzschelæsning, og som ikke opfatter en syfilistæret hjerne som en uoverstigelig hindring for en ærlig besindelse på konsistent fortolkningsmæssigt arbejde. Godt udført, det er det, og man kan følgelig kun håbe, at bogen også finder sine danske læsere.

ANDERS DREBY SØRENSEN

\section{Eksistentiel terapi i overblik}
Mick Cooper: Eksisten- tielle terapier, Dansk Psykologisk Forlag, 2011 , 272 sider, 298 kr.

Da filosofi i reglen betragtes som et førvidenskabeligt generaliststudie, og den konventionelle psykoterapi og kliniske psykologi sædvanligt opfattes som en klinisk fagpraksis, er det ikke særligt almindeligt at sammenkoble de to umiddelbart meget heterogene discipliner. Den mest udbredte undtagelse er den eksistentielle terapi, som er en filosofisk terapimetode, der, som en indre rumlen fra 1930erne og frem til i dag, har udfordret det konventionelle psyfaglige kompleks bestående af de fire fagområder: psyko- 
terapi, psykiatri, klinisk psykologi og psykopatologi. Ja, og så omfatter den eksistentielle terapi faktisk ikke én metode men en række beslægtede skoledannelser, der på forskellig vis har gjort sig historisk gældende gennem efterhånden 9 årtier. Dette påpeger Mick Cooper ganske rigtigt $\mathrm{i}$ introduktionen til sit overblik over de vigtigste af disse historiske skoledannelser, som nu er blevet oversat til dansk. Således omfatter fænomenet eksistentiel terapi en slags idémosaik af indbyrdes forbundne terapeutiske praksisser, der deler en orientering mod menneskets levede eksistens i sammenhæng med et træk på eksistensfilosofiske og fænomenologiske indsigter. Og det er denne helhedsorientering mod mennesket, som gør mosaikken til noget idé- og praksishistorisk unikt inden for et fagkompleks, der siden sin videnskabeliggørelse i løbet af det 19. århundrede ellers har haft en udpræget tendens til at reducere det menneskelige til nogle bestemte psykiske eller biologiske livsfunktioner.

På et tidspunkt, hvor filosofisk tænkning ellers er blevet fuldstændigt delegitimeret og ekskluderet fra psyfagene, melder den eksistentielle terapi sin ankomst i Schweiz, ved at insistere på en eksplicit integrering af filosofiske princip- per i den terapeutiske praksis med lidende mennesker. Efter en kort præsentation af de væsentligste principper fra den eksistensfilosofiske og -fænomenologiske tradition, gør Cooper i bogens kapitel 3 rede for, hvordan psykiateren og psykoanalytikeren Ludwig Binswanger i 1930erne falder over Martin Heideggers Daseinsanalytik $i$ et forsøg på at give psykiatrien et mere humant fundament og gøre den til en slags antropologisk videnskab om menneskelig misere, der følgelig får betegnelsen Daseinsanalyse. Mesteren Heidegger selv afsværger Binswangers omformning af sin lære som noget forkludret miskmask, men er ikke uinteresseret i koblingen mellem filosofi og terapi og tager i slutningen af 1950erne imod en invitation fra en anden schweizisk psykiater og psykoanalytiker, Medard Boss, til at bidrage til udformningen af en ny ontologisk fundering af psykoanalysen, der er befriet for Sigmund Freuds komplekse vokabular og fantasmagoriske metapsykologiske teoriapparat. Resultatet bliver en ny version af Daseinsanalysen, der sigter mod at gøre patienten i stand til at udfolde sine indre muligheder for at relatere sig $\mathrm{i}$ åbenhed mod verden. Som Cooper beskriver, udklækker Boss ikke mindst en interessant tilgang til drømmeterapi på 
dette grundlag, men hans redegørelse for Daseinsanalysens udvikling stopper desværre også hermed. Det kunne have været interessant om Cooper også havde formået at indføje de nyere bidrag til Daseinsanalysen, ikke mindst hos Gion Condrau og særligt hos Alice Holzhey-Kunz, der har ført projektet videre $\mathrm{i}$ en mere hermeneutisk retning. For en rent idéhistorisk betragtning havde det endelig været interessant, om bogen havde diskuteret den direkte indflydelse, som Daseinsanalysen fik på Michel Foucaults tidlige kritik af den konventionelle psykologi og psykiatri.

I kapitel 4 tager Cooper fat om Viktor Frankls logoterapi, der, modsat hvad mange tror, allerede var vel i støbeskeen, inden Frankl endte i Auschwitz, som han mirakuløst overlevede, og hvorfra han inddrog sine erfaringer $i$ sit terapeutiske projekt. Logoterapien kaldes også den tredje Wienerskole inden for psykoterapien, efter psykoanalysen og individualpsykologien, og til forskel fra Daseinsanalysen er Frankls bestræbelse på en modifikation af den psykoanalytiske psykoterapi bredt inspireret af den eksistensfilosofiske tradition i datidens Europa. Kernen hos Frankl er en idé om at menneskets væsen hverken er en viljen til magt, som hos Friedrich Nietzsche, eller en vilje til driftstilfredsstillelse, som hos Freud, men derimod en vilje til mening, og eksistentiel misere er følgelig tæt knyttet til en oplevelse af meningsløshed, mens terapiens opgave er en meningsrestaurering. Igen stopper Cooper her ved hovedaktøren og glemmer at redegøre for logoterapiens videreudvikling efter Frankl.

Kapitel 5 tager os til USA, hvor den eksistentielle terapi fik en meget individorienteret udformning, der ikke mindst blev udviklet af Rollo May, James Bugental, Kirk Schneider og Irvin Yalom, som også er bredt kendt i Danmark. Denne amerikanske ExistentialHumanistiske (E-H) bevægelse gør sig stadig gældende men blev historisk imidlertid også flankeret af en anden udvikling inden for psykologien og psykoterapien, som Cooper ikke medtager i sin bog, nemlig den humanistiske psykologi og den personorienterede terapi hos Carlo Rogers og Abraham Maslow, der ligeledes trak på eksistensfilosofiske indsigter.

I kapitel 6 lander vi på de britiske øer i 1960erne og 1970erne, hvor den skotske psykiater Ronald Laing skabte voldsom ravage inden for psykatriens idéologiske og institutionelle mure gennem udviklingen af en eksistensfænomenologisk psykiatri, der både trak bredt på 
Daseinsanalysen, eksistensfilosofien hos bl.a. Søren Kierkegaard samt Martin Buber, Heideggers eksistensfænomenologi og ikke mindst Jean-Paul Sartres analyse af 'blikket' fra værket L'etre et le neant men også Gregory Batesons systemteori, Palo Alto gruppen, Karl Marx og især Donald Winnicotts objektrelationsteori og teorien om det dobbeltsidede sande-falske selv. Resultatet var en dybt original og indsigtsfuld tilgang til skizofrenien som en meningsfuld væremåde, der måtte forstås ud fra den skizofrenes egenoplevelse af sin eksistens og dens erfarede trusler, og lige netop ikke ud fra psykiaterens klinisk objektiverende og dehumaniserende blik. Laing fulgte selv op på redegørelsen for den skizofrenes spaltede selv gennem et forfatterskab, der demonstrerede hvordan skizofrenien ikke blot var resultatet af dysfunktionelle familiestrukturer, men $i$ en mere omfattende forstand af en fremmedgørende kulturorden. Ganske kort gør Cooper afslutningsvis rede for, hvordan Laings arvinger deler sig i en psykoanalytisk lejr, der bl.a. omfatter The Philadelphia Association og som $i$ et vist omfang har inddraget filosofiske indsigter fra Emmanuel Levinas, Ludwig Wittgenstein og Jacques Derrida, og en mere eksistentiel lejr.

I kapitel 7 forbliver vi $\mathrm{i}$ det britiske, hvor Laings fremmeste arvinger ikke mindst findes $i$ den Britiske Eksistensanalyse, hvis primus motor har været den hollandske filosof og psykolog Emmy van Deurzen, der ikke blot har forsøgt at integrere principper og indsigter fra alle de tidligere skoledannelser inden for eksistentiel terapi samt hele den eksistens-filosofiske og -fænomenologiske tradition, men også meget eksplicit har fremstillet eksistensanalysen som en form for praktisk filosofi, der i væsen adskiller sig fra de former for psykoterapi, der er funderet i psykologien og psykiatrien. Samtidig er Deurzen tydeligt bevidst om eksistensanalysens slægtskab med den oldgræske etik som praktisk livskunst, og resultatet er en såkaldt onto-dynamisk terapi, hvis mål er at hjælpe den ulykkelige med at lære kunsten at leve sit eget liv. I den forbindelse tager Deurzen markant afstand fra hele den såkaldte positive bevægelse omkring den positive psykologi, flow-teorien og lykkeforskningen ved at insistere på at det liv, der skal leves, er komplekst og mangesidet og både rummer glæder og sorger.

Sammenlagt er Coopers bog en interessant og tiltrængt oversigt over den eksistentielle terapi, der både kan læses af psykologiske og filosofiske fagfolk. 